\title{
Factors Contributing to Students' Habit in Learning English
}

\author{
Tawali $^{1}$, Kamarudin ${ }^{2}$ \\ ${ }^{12}$ English Language Education, Faculty of Culture, Management, and Business, Mandalika University of \\ Education \\ Email: tawaliundikma@gmail.com ${ }^{1}, \underline{\text { kamarudin.ntbe@gmail.com }}^{2}$
}

\begin{abstract}
This research aimed at finding out Factors Contributing to Students' Habit in Learning English. The research was descriptive qualitative research. The subject of the study consisted of 25 students taken from five classes at the fifth semester students of FMBM. The instrument that was in the form of questionnaire. The result was analyzed by using Mile and Huberman (1994) theory (data reduction, data display, conclusion drawing and verification). The result found that there were five factors contributing to students' habit in learning English especially speaking skill at the fifth semester students of FMBM, they were; Performance Conditions, Affective Factors, Listening Ability, Topical Knowledge, and Feedback during Speaking Activities. And the more dominant factor among those factors were; Performance Conditions (20)/90\%, Affective Factors (18)/85\%, Topical Knowledge (15)/75\%, Listening Ability (10)/35\%, and Feedback during Speaking Activities (5)/10\%.
\end{abstract}

Key Words: Factors Contributing Students'Speaking Habit, Learning English

\section{INTRODUCTION}

Using language to communicate is beneficial. By mastering of a language, people can express ideas, share stories, tell experiences or desire to convey something. Recently, English language has been used in many parts of the world. English also has influenced our culture, life style and every element of science and technology. That is why Crystal (in Jazadi, 2008) said that English, because of its contribution has now reached global status. On the other hand, we can say English is clearly contributing significantly due to the spread of English in every element of life.

In educational level, teaching and learning English has been formally instructed as a compulsory subject in Junior and Senior high school since 1945. In addition, teaching and learning English is in accordance with the recommendation of government' curriculum polices (Jazadi, 2008). That indicates that students have enormous time to devour English fluently. However, it is still hard to find out the students who qualify and master it after graduating.

One of the problems is how the language is to be taught and studied. As Harmer (1998) said there are four things which are needed to do to acquire language, those are to be exposed, understanding its meaning, understanding its form then practicing the language.
Based on the illustration above, and the pre-observation that the researcher did at FMBM, most of the students do not master English language especially speaking skill because of some factors, especially contributing to the speaking's habit at campus.

\section{LITERATURE REVIEW}

\section{A. Speaking Skill}

One of the characteristics of a communicative view of language is a system for expressing of meaning. Its primary function is for interaction and communication, Richard and Rougher (in McDonough and Shaw, 2003).

This shows how speaking skills can be accommodated within this view of language. In the case, when the speakers use spoken language in the classroom, we as the speakers require the students to take part in a process that not only involves a knowledge of target forms and functions, but also a general knowledge of the interaction between the speakers and the listeners in order that meanings and negotiation of meanings are made clear.

Burns and Joyce (1999) give a description how young children in their early age speak that is making meaning. The linguistic elements including sounds and the grammatical structures of mother tongue are as their tools for exchanging meanings with the others. 
Speaking is somewhat different from writing. When speech is written down it appears far more disorganized and chaotic than written language, yet in real spoken interactions speakers are readily able to understand and respond each other (Burns and Joyce, 1999). This may involve expressing ideas and opinions, expressing a wish or a desire to do something, negotiating or solving a particular problem or establishing and maintaining social relationships and friendships (McDonough and Shaw, 2003). To achieve the purposes, we, as the speakers, should be able to activate the appropriate expressions.

The goal of teaching speaking is communicative efficiency. Hammond (in Burns and Joyce,1999) said the term "communicative" has often been interpreted as relating to speaking only, and in some cases, this has meant that teaching speaking has taken precedence over the teaching of reading and writing.

Furthermore, the development of speaking is an ongoing and complex process of acquiring knowledge and developing skills and strategies to interact with people in social interaction.

\section{B. Teaching Speaking in Indonesia as a Foreign Language}

Dardjowidjojo (in Jazadi,2008) adds that English is the first foreign language taught in Indonesia and is then prioritized rather than other foreign languages such as French, Arabic or German. In 1967, as it was elaborated by The Ministry of Education that teaching English in Indonesia as a foreign language (EFL) was claimed to provide students with English text books and references (Jazadi, 2008).

Gebhard (2000) shows several problems faced by the English Foreign Language (EFL) or English Second Language (ESL) teachers in teaching speaking; students will not talk that EFL or ESL teachers point out some students are so shy or having anxiety over speaking, error treatment that some teachers are concerned that students do not change their language, even after receiving feedback on their language errors, and any native speaker can teach conversation that there is a false assumption among teachers that any native speaker of English can teach the conversation class.

Ur (1996) also states four problems with speaking activities; inhibition, nothing to say, low or uneven participation and mother tongue use.

\section{Factors Contributing Students' Habit in Learning English Especially Speaking Skill}

Tuan and Mai, (2015) says that in order to help students overcome problems in learning speaking, it is necessary for the teachers to figure out factors that affect their speaking performance. Students' speaking performance can be affected by the factors that come from performance conditions (time pressure, planning, standard of performance and amount of support), affective factors (such as motivation, confidence and anxiety), listening ability and feedback during speaking activities .

\section{Performance Conditions}

Students perform a speaking task under a variety of conditions. Nation \& Newton (2009) believe that performance conditions can affect speaking performance. The four types of performance conditions that Nation \& Newton (2009) suggest include time pressure, planning, the standard of performance and the amount of support.

\section{Affective Factors}

One of the most important influences on language learning success or failure is probably the affective side of the learner (Oxford, 1990). Krashen (1982) states that a variety of affective variables has been confirmed to be related to success in second language acquisition in research over the last decade but most of those studies examined the three categories: motivation, self-confidence and anxiety.

\section{Listening Ability}

Speaking skills cannot be developed unless we develop listening skills (Doff, 1998). Students must understand what is said to them to have a successful conversation. Shumin (1997) shares the 
ideas of Doff (1998) by stating that when one person speaks, the other responds through attending by means of the listening process. In fact, every speaker plays the role of both a listener and a speaker. Therefore, one is certainly unable to respond if he/ she cannot understand what is said. It means speaking is closely related to listening.

\section{Topical Knowledge}

Topical knowledge is defined as knowledge structures in long-term memory (Bachman \& Palmer, 1996). In other words, topical knowledge is the speakers' knowledge of relevant topical information. The information that topical knowledge provides enables learners to use language with reference to the world in which they live. Bachman \& Palmer (1996) state certain test tasks may be easier for those who possess the relevant topical knowledge and more difficult for those who do not. Bachman \& Palmer (1996) believe that topical knowledge has effects on speaking performance.

\section{Feedback During Speaking Activities}

Most students want and expect their teachers to give them feedback on their performance. However, all speaking production should not be dealt with in the same way. Harmer (1991) asserts that the decisions that the teachers make about how to react to students' performance will depend upon the stages of the lesson, the activities, the types of mistakes made and the particular student who is making that mistake. If the teachers correct whenever there is a problem, the conversational flow as well as the purpose of the speaking activity will be destroyed (Harmer, 1991). If the students are corrected all the time, they can find this very demotivating and become afraid to speak. They suggest that the teachers should always correct the students' mistakes positively and with encouragement (Baker \& Westrup, 2003).

Those are five reasons or factors of learning English, particularly speaking skill. Once people can speak English fluently, he or she will get many opportunities to find out job, money, relationship, friends, etc. Thus, mastering English speaking bring us to the bright future of life. People will concern much on a person who is capable of speaking English correctly. So, through this study, the researcher is interested in investigating the factors contributing students' habit in learning English especially speaking skill. From these factors, which of the factors are more dominantly chosen by the students of the fifth semester of FBMB.

\section{Speaking Problems}

Ur (1996), there are some speaking problems that teachers can come across in getting students to talk in the classroom. These are: inhibition, lack of topical knowledge, low or uneven participation and mother-tongue use.

\section{RESEARCH METHOD}

\section{A. Research Design}

The present study is a descriptive qualitative research, since it was intended to know the factors contributing to students' habit in learning English. According to Talbot $(1995: 25)$ that descriptive qualitative study is the method of choice when straight descriptions of phenomena are desired. Such study is especially useful for researchers wanting to know who, what, and where of events. Although foundational to all qualitative research approaches, qualitative descriptive studies comprise a valuable methodological approach in and of themselves.

\section{B. Subject of the Study}

In this research, the writer took 25 students taken from five classes at the fifth semester students of FBMB as the subject of the research. Each class was taken 5 students as the representative. So, the total number of samples of the research was 25 students.

\section{Techniques of Data Collection}

The technique used to collect the data was questionnaire. It was to find out and support the main data. The questionnaire was done in order to focus on factors contributing to students' habit in learning English especially speaking skill at the fifth semester students of FBMB in the classroom. The questionnaire was also be done in order to 
support the observation data to validate the complement and the result of the research. During the research, the researcher asked the students to fill the blank on the questionnaire sheets and then submitted to the researcher in order to be analyzed.

\section{Technique of Data Analysis}

The data of questionnaire was used to describe the data obtained. Here are some procedures of data analysis that the researcher did. In analyzing the data, itself, the researcher used some steps to make it easily. In relation to the data analysis, here the researcher used the procedures of data analysis by Mile and Huberman (1994) they are;

\section{Data Reduction}

Data reduction refers to the process of selecting, focusing, simplifying, abstracting, and transforming the data that appear in written-up field notes or transcriptions (Miles, and Huberman: 1994). After the data obtained, then it is transcribed into transcription sheets or tabulating the data, the researcher then analyzes them. After that, the writer determined which data were relevant to the research questions or doing data reduction.

\section{Data Display}

Data display is an organized, compressed assembly of information that permits conclusion drawing and action, (Miles, and Huberman, 1994). After doing data reduction, then the researcher displayed the findings in the form of tabulation checklist and give the conclusion.

\section{Conclusion Drawing and Verification}

After doing, data reduction, and data display then the researcher drew conclusion and verification. It was the data related to the students' factors contributing students' habit in learning English, then followed by findings, and then ended through the conclusion or report. The description is represented in the qualitative narrative passage. The narrative passage was conducted in order to convey the findings and conclusion of the study.

\section{FINDING AND DISCUSSION}

This part deals with data finding about factors contributing to the students' habit in speaking English at the fifth semester of FBMB. After conducting the research, the researcher found some findings.

1. Finding.

A. Factors contributing to students' habit in learning English especially speaking skill at the fifth semester students of FBMB.

\begin{tabular}{|l|l|l|l|}
\hline No & $\begin{array}{l}\text { Factors } \\
\text { contributing to } \\
\text { Students' Habit } \\
\text { In Speaking } \\
\text { Skill }\end{array}$ & \multicolumn{2}{|c|}{ Number of Students } \\
\cline { 3 - 4 } & \multicolumn{1}{|c|}{ Yes } & No \\
\hline 1 & $\begin{array}{l}\text { Performance } \\
\text { Conditions }\end{array}$ & $(20) / 90 \%$ & $(5) / 10 \%$ \\
\hline 2 & Affective Factors & $(18) / 85 \%$ & $(7) / 15 \%$ \\
\hline 3 & Listening Ability & $(10) / 35 \%$ & $(15) / 75 \%$ \\
\hline 4 & $\begin{array}{l}\text { Topical } \\
\text { Knowledge }\end{array}$ & $(15) / 75 \%$ & $(10) / 35 \%$ \\
\hline 5 & $\begin{array}{l}\text { Feedback During } \\
\text { Speaking } \\
\text { Activities }\end{array}$ & $(5) / 10 \%$ & $(20) / 90 \%$ \\
\hline
\end{tabular}

\section{Data Description:}

From the data in the table above, it can be seen that there are five factors contributing to students' habit in learning English especially speaking skill at the fifth semester students of FBMB. They are; Performance Conditions, Affective Factors, Listening Ability, Topical Knowledge, and Feedback during Speaking Activities. This finding was found during the researcher conducted the research by distributing the questionnaire to 25 students of class B, C, D, E and F.

$B$. The dominant factors that contributing to students' habit in learning English especially speaking skill at the fifth semester students of FBMB.

\begin{tabular}{|c|l|c|c|}
\hline No & $\begin{array}{c}\text { Factors } \\
\text { contributing to } \\
\text { Students' Habit In } \\
\text { Speaking Skill }\end{array}$ & \multicolumn{2}{|c|}{} \\
\cline { 3 - 4 } & \multicolumn{2}{|c|}{ Yes } & No \\
\hline 1 & $\begin{array}{l}\text { Performance } \\
\text { Conditions }\end{array}$ & $(20) / 90 \%$ & $(5) / 10 \%$ \\
\hline 2 & Affective Factors & $(18) / 85 \%$ & $(7) / 15 \%$ \\
\hline 3 & Listening Ability & $(10) / 35 \%$ & $(15) / 75 \%$ \\
\hline 4 & Topical Knowledge & $(15) / 75 \%$ & $(10) / 35 \%$ \\
\hline 5 & $\begin{array}{l}\text { Feedback During } \\
\text { Speaking Activities }\end{array}$ & $(5) / 10 \%$ & $(20) / 90 \%$ \\
\hline
\end{tabular}

\section{Data Description}

From the data elaborated above, the researcher took the conclusion on the most 
dominant factors that contributing to students' habit in learning English especially speaking skill at the fifth semester students of FBMB. They are;

1. Performance Conditions. This factor was selected by 20 students or it is around $90 \%$ of the students.

2. Affective Factors. This factor was selected by 18 students or it is around $85 \%$ of the students.

3. Topical Knowledge. This factor was selected by 15 students or it is around $75 \%$ of the students.

4. Listening Ability. This factor was selected by 10 students or it is around $35 \%$ of the students.

5. Feedback during Speaking Activities. This factor was selected by 5 students or it is around $10 \%$ of the students.

Meanwhile, here, the researcher also gave additional explanation that the number of students who did not choose those factors was;

1. Performance Conditions. This factor was not selected by 5 students or it is around $10 \%$ of the students.

2. Affective Factors. This factor was not selected by 7 students or it is around $15 \%$ of the students.

3. Listening Ability. This factor was not selected by 15 students or it is around $75 \%$ of the students.

4. Topical Knowledge. This factor was not selected by 10 students or it is around 35\% of the students.

5. Feedback during Speaking Activities. This factor was not selected by 20 students or it is around $90 \%$ of the students.

From the data finding above, it is seen that the students were highly affected by performance condition in their speaking habit. And then followed by affective factor, and then followed by listening ability, followed by topical knowledge, followed by feedback during speaking activities.

Meanwhile, from those five factors contributing to students' habit in learning English especially speaking skill at the fifth semester students of FMBM, we can see that students were affected by those five factors in performing speaking skill. So, if we want to teach the students to speak English especially in FMBM, the teachers or lecturers may use this research finding as one of their references so that they can know the strength and weaknesses of their students in speaking class, and they will know the factors that may contribute them much in speaking skill at any context and speaking contribution. Thus, speaking factors are very important to be known because each students has different capability to utter their speaking skill.

\section{DISCUSSION}

Based on the research finding gained after doing the research, then in this part, the researcher elaborated the discussion of the data. It means that the researcher did this elaboration in terms of giving further information on the data analysis based on the research question given.

From the questionnaire given to the students, it can be concluded that the number of students who selected "yes" in the first factor was 20 students, and "no" was 5 students. And the number of students who selected "yes" in the second factor was 18 students, and "no" was 7 students. The number of students who selected "yes" in the third factor was 10 students, and "no" was 15 students. The number of students who selected "yes" in the fourth factor was 15 students, and "no" was 10 students. The number of students who selected "yes" in the fifth factor was 5 students, and "no" was 20 students.

Meanwhile the percentage of each factor that the students selected during the research or to the questionnaire given to them were; the number of students who selected "yes" in the first factor was $90 \%$ students, and "no" was $10 \%$ students. The number of students who selected "yes" in the second factor was $85 \%$ students, and "no" was $15 \%$ students. The number of students who selected "yes" in the third factor was $35 \%$ students, and "no" was $75 \%$ students. The number of students who selected "yes" in the fourth factor was $75 \%$ students, and "no" was 35\% students. And the number of students who selected "yes" in the fifth factor was $10 \%$ students, and "no" was $90 \%$ students. 
After conducting the research about the factors contributing to students' habit in learning English especially speaking skill at the fifth semester students of FMBM, and formulated two questions, in which one of those questions was about which of the factors are more dominant among other factors.

Looking at the questionnaire result given to the students, it was seen that the most dominant factors were; The first dominant factor was performance condition represented in the question "Apakah anda merasa senang kalau speaking didukung oleh fasilitas yang baik, kondisi yang bagus, dan didukung pada saat latihan speaking di kelas?" was 20 (90\%) students selected it and $5(10 \%)$ students were not.

The second dominant factor was affective factor represented in the question "Apakah anda merasa termotivasi pada saat memiliki self-confident yang baik?" was 18 (85\%) students selected it, and 7 (15\%) students were not.

The third dominant factor was topical knowledge represented in the question "Apakah anda merasa tidak ingin praktik speaking lagi pada saat anda tidak tau topic atau materi yang mau anda bicarakan?" was 15 (75\%) students selected it, and $10(35 \%)$ students were not.

The fourth dominant factor was listening ability represented in the question "Apakah anda merasa terpengaruhi tingkat kebiasaan anda speaking pada saat lawan bicara anda tidak mengerti apa yang anda bicarakan?" was $10(35 \%)$ students selected it, and $15(75 \%)$ students were not.

The last or the fifth dominant factor was feedback during speaking activities represented in the question "Apakah anda mereasa tidak senang ketika ada lawan bicara anda tidak memberikan feedback pada saat speaking, dan apakan itu akan mempengaruhi anda untuk ingin berlatih speaking di kelas?" was $5(10 \%)$ students selected it, and $20(90 \%)$ students were not.

\section{CONCLUSIONS AND SUGGESTION}

After conducting the research, the researcher comes to the conclusion that it was found that there were two conclusions based on the research question in this research. They were;

1. There were five factors contributing to students' habit in learning English especially speaking skill at the fifth semester students of FMBM. They were; Performance Conditions, Affective Factors, Listening Ability, Topical Knowledge, and Feedback during Speaking Activities.

2. The more dominant factor among those factors were; ; Performance Conditions (20)/90\%, Affective Factors (18)/85\%, Topical Knowledge (15)/75\%, Listening Ability (10)/35\%, and Feedback during Speaking Activities (5)/10\%.

\section{REFERENCES}

Bachman, L., \& Palmer, A. S. (1996). Language Testing in Practice. Oxford: Oxford University Press.

Baker, J., \& Westrup, H. (2003). Essential Speaking Skills: A Handbook for English Language Teachers. London: Continuum.

Burns, A. and Joyce, H. 1999. Focus on Speaking. Sydney: Macquarie University.

Doff, A. (1998). Teach English: A training Course for Teacher. Cambridge University Press

Gebhard, J. G. 2000. Teaching English as a Foreign or Second Language. America: The University of Michigan Press.

Harmer, J. (1991). The Practice of English Language Teaching. The 3th Edition. Longman: London and New York

Harmer, Jeremy. 1998. How to Teach English: An Introduction to the Practice of English Language Teaching. Malaysia: Longman.

Jazadi, Iwan. 2008. The Politic of Curriculum (an Interpretive Study of English Language Teaching and Learning at High School in Indonesia). Lempeh Sumbawa Besar: Paracendikia NW Press. 
Krashen, S. D. (1982). Principles and Practice in Second Language Acquisition. New York: Pergamon Press.

McDonough, Jo and Shaw, C. 2003. Materials and Method in ELT. Malden: Blackwell Publishing Ltd.

Miles, B. Matthew, Huberman, A. Michael. (1994). Qualitative Data Analysis. Second Edition. London: Sage Publication.

Nation, I. S. P., \& Newton, J. (2009). Teaching ESL/EFL Listening and Speaking. ESL \& Applied Linguistics Professional Series. Routledge Taylor \& Francis Group

Oxford, R. L. (1990). Language Learning Strategies: What Every Teacher Should Know. New York: Newbury House Publishers.

Shumin, K. (2002). Factors to Consider: Developing Adult EFL Students Speaking Abilities. In J. C. Richards, \& W. A. Renandya (Eds.), Methodology in Language Teaching (pp.204-211). Cambridge: Cambridge University Press.

Talbot, L.A. (1995). Principles and Practice of Nursing Research.St. Louis, MO: Mosby-Year Book.

Tuan, Nguyen Hoang, And Mai, Tran Ngoc. 2015. Factors Affecting Students' Speaking Performance At Le Thanh Hien High School. Asian Journal of Educational Research. Vol. 3, no. 2, 2015 ISSN 2311-6080.

Ur, Penny. (1996). A Course in Language Teaching: Practice and Theory. Cambridge: Cambridge University Press. 